\title{
Fern species diversity across various land use types of Mt. Makiling, Luzon Island, Philippines
}

\author{
AILENE A. ALCALA ${ }^{\natural}$, MARJORIE D. DELOS ANGELES ${ }^{\bullet}$, INOCENCIO E. BUOT, JR. \\ Plant Biology Division, Institute of Biological Sciences, College of Arts and Sciences, University of the Philippines Los Baños, Laguna, Philippines. \\ Tel.: +63-49-5362807, •email: aaalcala1@up.edu.ph,••mddelosangeles@gmail.com
}

Manuscript received: 7 June 2019. Revision accepted: 6 August 2019.

\begin{abstract}
Alcala AA, Delos Angeles MD, Buot Jr IE. 2019. Fern species diversity across various land use types of Mt. Makiling, Luzon Island, Philippines. Biodiversitas 20: 2437-2445. Mt. Makiling of Luzon Island, Philippines is home to many living organisms including ferns and fern allies which are one of the important understory vegetation in many forest communities and having various economic uses like food, medicine and ornamentation. This study identified fern species found in various land use types across the northeastern slope of Mt. Makiling, Los Baños, Philippines. The plot technique was employed using a 20x20 meter quadrat. Three (3) 5x2 subquadrats were randomly distributed within the established quadrat. Fern specimens were identified (sensu PPG 2016) and measured. Samples were collected for herbarium voucher deposited in the PBDH. A total of 28 fern species with 22 genera from 14 families were found across land use types. Identified land use types were: (i) Mahogany (341 m asl.); (ii) Agriculture (355 m asl.); (iii) Buffer zone (365 m asl.); (iv) Agroforest (368 m asl.); (v) Roadside (455 m asl.), and (vi) Forest (482 $\mathrm{m}$ asl.). The most represented fern families were found out to be Thelypteridaceae ( $5 \mathrm{spp}$ ), Dryopteridaceae (3 spp), Polypodiaceae (3 spp.), Pteridaceae ( $3 \mathrm{spp})$, Aspleniaceae ( $2 \mathrm{spp}$ ), Dennstaedtiaceae (2 spp), Selaginellaceae (2 spp.) and Tectariaceae (2 spp.). On the other hand, the families Schizaeaceae, Lindsaeaceae, Davalliaceae, Nephrolepidaceae, and Marratiaceae are comprised of one species only. Pteris blumeana C. Agardh and Tectaria crenata Cav. were found only in buffer zone area. Dennstaedtia philippinensis Copel., Lygodium circinnatum (Burm. f.) Sw. and Microlepia sp., were found only in agroforest area; Sphaerostephanos unitus (L.) Holttum found only in agricultural; Bolbitis heteroclita (C. Presl) Ching and Microsorum membranifolium (R. Br.) Ching were found in roadside while Asplenium tenerum G. Forst., Christella sp., Lindsaea fissa Copel. and Nephrolepis cordifolia (L.) C. Presl were found in forest area. Pneumatopteris nitidula (C. Presl) Holttum. is a dominant fern species found in agriculture and mahogany plantation area. There is a need to document fern species along with its population across land use types in order to utilize ferns as plant indicators due to their vulnerability to changes in environmental conditions. These results can shed light on the appropriate strategy for the conservation and management of ferns in Mt. Makiling.
\end{abstract}

Keywords: Fern diversity, land use types, Mt. Makiling, pteridophytes

\section{INTRODUCTION}

Mt. Makiling is one of the best known biological areas and one of the 18 centers for plant diversity in the Philippines (Lapitan et al. 2010). The different physical types of vegetation is similar to those natural on many, if not most, mountain peaks rising from the lowlands in moist tropical regions. According to Fernando et al. (2004) there are four types of vegetation recognized in the mountain based on altitude: upper montane rain forest $(>1000 \mathrm{~m}$ asl.), lower montane forest (>750 $\mathrm{m}$ asl.), lowland evergreen forest (100-500 m asl.), and parang vegetation (< $100 \mathrm{~m}$ asl.). Ferns and their allies are one of the important understorey vegetation in many forest communities. Ferns can be used as food and ornamentals (Zamora and Co 1986; Buot 1999; Banaticla and Buot 2008; Delos Angeles and Buot 2012). It also has medicinal value found in this plant (Amoroso 1987b; Zamora and Co 1986; Delos Angeles and Buot 2012). Fern species are spore-bearing plants growing in moist shaded habitat although some can grow under strong sunlight in very dry environment.

Few studies on the pteridophyte flora of Philippine mountains have been carried out. There are approximately 1,100 species, with 144 genera and 39 families of Pteridophytes reported to be present in the Philippines (Barcelona 2002; Banaticla and Buot 2008; Pelser et al. 2011; Delos Angeles and Buot 2012; Amoroso et al. 2016). It was reported that 899 species of ferns in the Philippines are endemic in the Philippines (Delos Angeles and Buot 2012; Zamora 2007). In Mindanao, Amorsolo et al. (1996) studied the diversity, status and ecology of pteridophytes in three forests, i.e. Mt. Kitanglad has 275 species; Mt. Apulang and Marilog forest has 249 species and 183 species, respectively. In Mt. Pangasugan, Baybay Leyte, a total of 93 species of pteridophytes belonging to 24 families and 55 genera were collected and found at 5 to 400 masl (Belonias and Bañoc 1994). The study of Barcelona (2003) on the pteridophyte flora of Mt. Iraya, Batan Island, Batanes revealed that the area caters 89 species in 47 genera and 25 families. Tolentino (1988) worked on the fern flora of Mt. Santo Tomas, Benguet and documented 100 species. In Mt. Makiling, a total of 27 species under 18 genera and 14 families were identified (Delos Angeles and Buot 2015). Pteridophytes are excellent bioindicators in recognizing the altitudinal zonation of tropical mountains (Frahm and Gradstein 1991).

In a study conducted by Delos Angeles and Buot (2018) in Mt. Makiling, three zones were identified using dendrogram by average clustering. These zones were: (i) Bolbitis- 
Lindsaea zone, (ii) Lygodium-Christella zone; and (iii) Sphaerostephanos-Selaginella zone. Fern species may also be used as bioindicators for different land use types. The study was conducted to: (i) identify and document fern species found in various land use types across the northeastern slope of Mt. Makiling and; (ii) to determine the distribution and current conservation status of the identified fern species through the use of published literature.

\section{MATERIALS AND METHODS}

\section{Study area}

The study was conducted during the wet season of June 2018 at Mt. Makiling, Los Baños, Laguna, Philippines (Figure 1). The mountain is an important training laboratory for the conservation and development of forests and associated ecosystems. Mt. Makiling (1,090 m asl.) is surrounded by regions with sharply alternating wet and dry seasons, so its immediate vicinity has a mild climate. In terms of soil type, Mt. Makiling soils are classified as clay-loam type, which were derived from volcanic ash (Brown 1919).

A field reconnaissance survey was conducted in the study area as a confirmatory step to verify the presence of ferns in a different land use types in Mt. Makiling. The different land use types identified were: i) Mahogany (341 $\mathrm{m}$ asl.); (ii) Agriculture (355 m asl.); (iii) Buffer zone (365 $\mathrm{m}$ asl.); (iv) Agroforest (368 m asl.); (v) Roadside (455 m asl.), and (vi) Forest (482 $\mathrm{m}$ asl.). A Global Positioning
System (GPS) was used to record the coordinates of the identified land use type.

\section{Establishment of plots}

The plot technique was employed using a 20 x $20 \mathrm{~m}^{2}$ quadrat to inventory the different fern species observed. Within the established quadrat, three (3) 5 × 2 meter sub quadrats were randomly distributed. Three sub quadrats were established per land use type. In each sub quadrat, all observed ferns were considered samples. The number of individuals per species of fern found within the area was noted and recorded. Sample specimens were collected for herbarium use. The number of individuals of ferns per unit area was used as a measure of dominance.

\section{Fern identification}

The collected fern samples were re-examined at the Plant Systematics Laboratory, Plant Biology Division, Institute of Biological Sciences (IBS), College of Arts and Sciences (CAS), University of the Philippines Los Baños (UPLB), using a dissecting (20x) and compound microscope $(40 x)$. The unknown species were identified using the herbarium specimens at the Plant Biology Division Herbarium (PBDH), Plant Systematics Laboratory, IBS, CAS, UPLB, and the Philippine National Herbarium, National Museum in Manila. Fern specialists were also consulted for the identification of unknown specimens. The morphology and diagnostic characters of ferns were used for classification. Identified specimens were deposited to the Plant Biology Division Herbarium (PBDH).
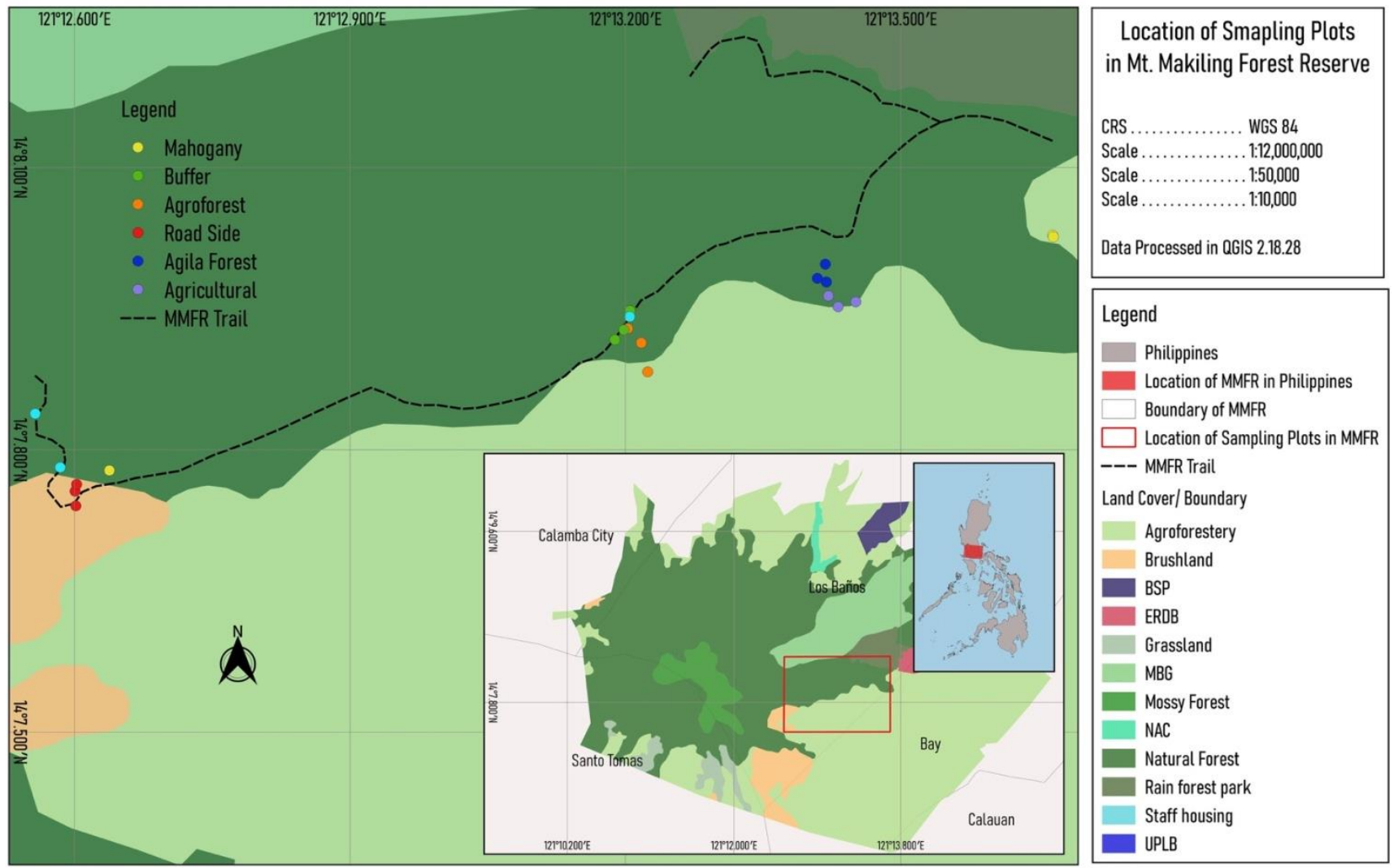

Figure 1. Location of the study site indicating the different land use types at the northeastern slope of Mt. Makiling, Los Baños, Philippines 


\section{RESULTS AND DISCUSSION}

\section{Fern species composition across land use types of Mt. Makiling}

Six (6) land use types were identified from Mt. Makiling. These land use types were: i) Mahogany (341 m asl.); (ii) Agriculture (355 m asl.); (iii) Buffer zone (365 m asl.); (iv) Agroforest (368 m asl.); (v) Roadside (455 m asl.), and (vi) Forest (482 $\mathrm{m}$ asl.) (Figure 2). Forest areas were represented by the growth of dipterocarps and plantations, including the tropical rain-forest park. Agroforestry areas are those where annual crops and fruit trees along with woody species are grown. Brush lands, grasslands and coconut plantations areas are also categorized as part of the agroforestry areas. Buffer zone is those areas designed to protect and intensify the conservation benefit of ecologically valuable areas (Soriano et al. 2019).

A total of 28 fern species with 22 genera from 14 families were found across the identified land use types (Table 1). Based on its important values, the pteridophyte flora of Mount Makiling across land use types was dominated by the following fern families: Thelypteridaceae (5 spp), Dryopteridaceae (3 spp), Polypodiaceae (3 spp) and Pteridaceae (3 spp). The families Aspleniaceae, Dennstaedtiaceae, Selaginellaceae, and Tectariaceae are comprised of two (2) species each. Marattiaceae,
Davalliaceae, Schizaeaceae, Lindsaeaceae, and Nephrolepidaceae consist of one (1) species only.

\section{Dominant fern species in each land use type}

Dominant fern species for each land use type was determined. The Mahogany land use type can be found at an elevation of $341 \mathrm{~m}$ asl. It is a 60-year plantation heavily dominated by Swietenia macrophylla King (Lee, et al. 2010). This land use type harbors the lowest number of observed species with 6 fern species. Pneumatopteris nitidula (C. Presl) Holttum dominated this land use type. This particular fern species is utilized by the community as food, especially the crozier. It is enjoyed by the locals and is usually prepared as a salad.

The agricultural land use type is found at an elevation of $355 \mathrm{~m}$ asl. It refers to areas in the mountain with clearings by farmers for the plantation of crops (Buot and Osumi, 2011). Similar to the Mahogany land use type, the dominant fern species was Pneumatopteris nitidula (C. Presl) Holttum. This fern species is capable of colonizing areas with high anthropogenic activity such as agricultural areas. The fern species Sphaerostephanos unitus (L.) Holttum was only recorded in plots established in this particular land use type. It can be considered as an indicator species for agricultural land use types. Sphaerostephanos unitus (L.) Holttum can be found in degraded habitats generally, along waterways, and is very common at low to medium elevation (Pelser et al. 2011).
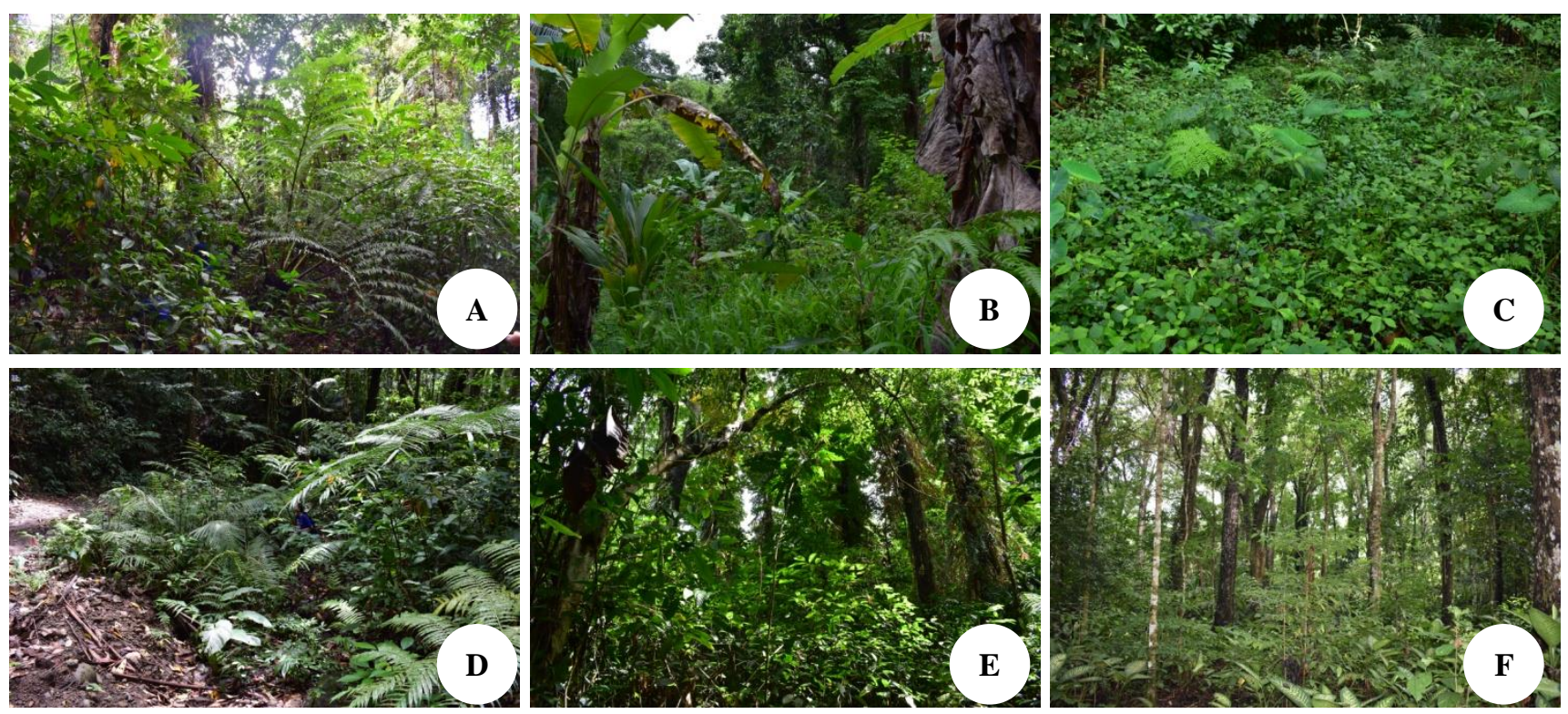

Figure 2. Identified different land use types in Mt. Makiling, Los Baños, Laguna, Philippines. Note: A. Buffer zone; B. Agroforest; C. Agriculture; D. Roadside; E. Primary forest, and F. Mahogany. 
Table 1. Frequency of pteridophytes (sensu PPG 2016) across land use types in Mt. Makiling Forest Reserve, Laguna, Philippines

\begin{tabular}{|c|c|c|c|c|c|c|c|c|}
\hline \multirow{2}{*}{$\begin{array}{l}\text { Class, } \\
\text { Order }\end{array}$} & \multirow{2}{*}{ Family } & \multirow{2}{*}{ Scientific name } & \multicolumn{6}{|c|}{ Land use types } \\
\hline & & & B & $\mathbf{A F}$ & $\mathbf{A}$ & $\mathbf{R}$ & $\mathbf{F}$ & $\mathbf{M}$ \\
\hline \multicolumn{9}{|l|}{ Lycopodiopsida } \\
\hline \multirow[t]{2}{*}{ Selaginellales } & Selaginellaceae & Selaginella sp. 1 & 9 & 5 & 0 & 0 & 2 & 0 \\
\hline & & Selaginella cupressina (Willd.) Spring & 5 & 0 & 0 & 5 & 0 & 0 \\
\hline \multicolumn{9}{|l|}{ Polypodiopsida } \\
\hline Marattiales & Marattiaceae & Angiopteris evecta (Forst.) Hoffm. & 10 & 1 & 0 & 6 & 7 & 1 \\
\hline Schizaeales & Schizaeaceae & Lygodium circinatum (Burm. f.) Sw. & 0 & 1 & 0 & 0 & 0 & 0 \\
\hline Lindsaeineae & Lindsaeaceae & Lindsaea fissa Copel. & 0 & 0 & 0 & 0 & 1 & 0 \\
\hline \multirow[t]{3}{*}{ Pteridineae } & Pteridaceae & Adiantum diaphanum Blume & 0 & 0 & 3 & 0 & 1 & 0 \\
\hline & & Pteris blumeana C. Agardh & 2 & 0 & 0 & 0 & 0 & 0 \\
\hline & & Pteris longipinnula Wall. ex J. Agardh & 1 & 0 & 0 & 0 & 2 & 1 \\
\hline \multirow[t]{2}{*}{ Dennstaedtiineae } & Dennstaedtiaceae & Dennstaedtia philippinensis Copel. & 0 & 2 & 0 & 0 & 0 & 0 \\
\hline & & Microlepia sp. & 0 & 1 & 0 & 0 & 0 & 0 \\
\hline \multirow{7}{*}{$\begin{array}{l}\text { Aspleniineae } \\
\text { (Eupolypods II) }\end{array}$} & Aspleniaceae & Asplenium sp. & 0 & 0 & 0 & 0 & 6 & 1 \\
\hline & & Asplenium tenerum $\mathrm{G}$. Forst. & 0 & 0 & 0 & 0 & 4 & 0 \\
\hline & Thelypteridaceae & Christella sp. & 0 & 0 & 0 & 0 & 38 & 0 \\
\hline & & Cyclosorus terminans (J. Sm. ex Hook.) K.H. Shing & 0 & 163 & 3 & 11 & 0 & 0 \\
\hline & & Sphaerostephanos hirsutus Holttum & 0 & 0 & 13 & 9 & 0 & 0 \\
\hline & & Sphaerostephanos unitus (L.) Holttum & 0 & 0 & 32 & 0 & 0 & 0 \\
\hline & & Pneumatopteris nitidula (C. Presl) Holttum & 2 & 2 & 28 & 0 & 0 & 38 \\
\hline \multirow{11}{*}{$\begin{array}{l}\text { Polypodiineae } \\
\text { (Eupolypods I) }\end{array}$} & Dryopteridaceae & Bolbitis heteroclita (C. Presl) Ching & 0 & 0 & 0 & 18 & 0 & 0 \\
\hline & & Bolbitis sinuata Hennipman & 1 & 0 & 0 & 0 & 2 & 0 \\
\hline & & Pleocnemia macrodonta Holttum & 19 & 2 & 1 & 3 & 9 & 0 \\
\hline & Nephrolepidaceae & Nephrolepis cordifolia (L.) C. Presl & 0 & 0 & 0 & 0 & 1 & 0 \\
\hline & Tectariaceae & Tectaria crenata Cav. & 3 & 0 & 0 & 0 & 0 & 0 \\
\hline & & Tectaria siifolia (Willd.) Copel. & 0 & 1 & 0 & 14 & 0 & 0 \\
\hline & Davalliaceae & Davallia hymenophylloides (Blume) Kuhn & 0 & 57 & 0 & 0 & 0 & 9 \\
\hline & Polypodiaceae & Microsorum longissimum Fée & 0 & 2 & 0 & 0 & 4 & 0 \\
\hline & & Phymatosorus membranifolium (R. Br.) S.G. Lu & 0 & 0 & 0 & 6 & 0 & 0 \\
\hline & & Phymatosorus scolopendria (Burm.f.) Pic. Serm. & 0 & 0 & 0 & 0 & 2 & 1 \\
\hline & & Total & 52 & 237 & 80 & 72 & 79 & 51 \\
\hline
\end{tabular}

Note: Values are the number of individuals found in the study plots. Note: B: Buffer, AF: Agroforest, A: Agriculture, R: Roadside, F: Forest, and M: Mahogany

The buffer land use type is a forested area in between the forest edge and the undisturbed forest (Buot and Osumi, 2011). The buffer zone is found at an elevation of $365 \mathrm{~m}$ asl. The dominant fern species was Angiopteris evecta (Forst.) Hoffm. It is commonly known as the king fern with heights reaching up to 7 meters and fronds that can reach up to 5 to 6 meters (Christenhusz, M., Toivonen, J.M., and Tuuli, K., 2008). In a study conducted by Magtoto and Austria (2017), Angiopteris evecta (Forst.) Hoffm can be observed in slopes and in inner forests. The fern species Pteris blumeana Agardh and Tectaria crenata Cav. are recorded only in plots established in the buffer land use type and are indicator species for this particular land use type.

The agro-forest land use type is found at an altitude of $368 \mathrm{~m}$ asl. It refers to open areas of the mountain where trees and shrubs are grown in association with economically important crops. The agroforest land use types were recorded to have 10 fern species. Despite being an anthropogenic ecosystem, agroforests can still harbor a higher number of species resulting in a higher number of fern species among the land use types. Ferns have strategies which allow them to adapt to more frequent disturbance and invest in rapid gametophyte growth and recruitment (Watkins, et al. 2007). The dominating fern species was Davallia hymenophylloides (Blume) Kuhn. Dennstaedtia philippinensis Copel., Lygodium circinnatum (Burm. F.) Sw., and Microlepia sp. can be considered as indicator species since they can only be found thriving in this particular land use type. Lygodium circinnatum (Burm. F.) Sw. are common in brush and open sites as well as in disturbed lowland forests (Pelser et al. 2011).

The roadside refers to vegetated area beside a road. The plot was established at an altitude of $455 \mathrm{~m}$ asl. A total of 8 fern species were observed in the area. The dominant fern species was Cyclosorus terminans (J. Sm. Ex Hook) K.H. Shing which is common in thickets on hillsides and in valleys at low and medium elevation (Pelser et al. 2011). It can be noted that ferns in the established plots for this land use type were thriving on rocks as well as along slopes. A 
rocky substrate provides a good substrate for ferns to root upon (delos Angeles and Buot 2018). Bolbitis heteroclita (C. Presl) Ching, and Phymatosorus membranifolium (R. Br.) S.G. Lu were limited to this land use type and thus can be considered as indicator species.

The primary forest can be found starting at an altitude of $482 \mathrm{~m}$ asl. It is a pristine forest with very little human encroachment. Forests are richer in species as compared to disturbed areas of the mountain. It was recorded to have the most number of observed species with 13 fern species. The dominant fern is Christella sp. Indicator species for this land use type are Asplenium tenerum, Christella sp., Nephrolepis cordifolia, and Lindsaea fissa Copel.

\section{Distribution and conservation status of fern species}

The climate in Mt. Pangasugan was Type IV which is characterized by frequent rainfall that is evenly distributed throughout the year (Polinar and Muuss, 2010). This climate is similar to that of Mt. Makiling. On the other hand, Mt. Iraya has unfavorable climatic conditions due to frequent strong winds and remoteness from mainland Luzon (Barcelona, 2003). Mt. Banahaw mountain complex is one of the 12 centers of plant diversity and endemism in the Philippines as recognized by the World Wildlife Fund/International Union for the Conservation of Nature (WWF/IUCN) (Mittermeier et al. 1997).

Some fern species recorded in Mt. Makiling were similar to that of Mt. Pangasugan, Mt. Iraya and Mt. Banahaw (Table 2). Angiopteris evecta (Forst.) is a fern species similar to both Mt. Pangasugan and Mt. Iraya only. It was noted that Pleocnemia macrodonta Holttum species were similar only with Mt. Pangasugan. The fern species similar only with Mt. Banahaw were Bolbitis sinuata Hennipman and Phymatosorus membranifolium (R. Br.) Ching. Only Bolbitis heteroclita (C. Presl) Ching and Christella sp. are the fern species similar to Mt. Iraya.

The existence of various microenvironment, as a result of stratified vegetation of the secondary forest, which allows niche variation for the pteridophytes. The tree ferns formed the lowest canopy layer with forest tree seedlings and large shrubs. Terrestrial ferns and clubmosses are very prominent components of the ground layer, especially along trails. Tree branches, fallen tree trunks, tree stumps and rock crevices in a various land use types is a very large array of epiphytic ferns and lycopsids. The moist and wet conditions are favorable for pteridophyte growth and reproduction (Banaticla and Buot 2004, Koptur and Lee 1993). The species success in occupying a particular area is determined by several biological and physical factors. The most conducive environmental conditions and the absence of other plant competitors would greatly favor species growth and reproduction. Species with wider tolerance range, climbing habit (Russel et al. 1998) and ability to reproduce asexually have more advantage than the others. However, the combined cover values of many different species occupying their own niches in a stratified forest community can equal or even surpass the combined cover values of a few species dominating an exposed grassland.
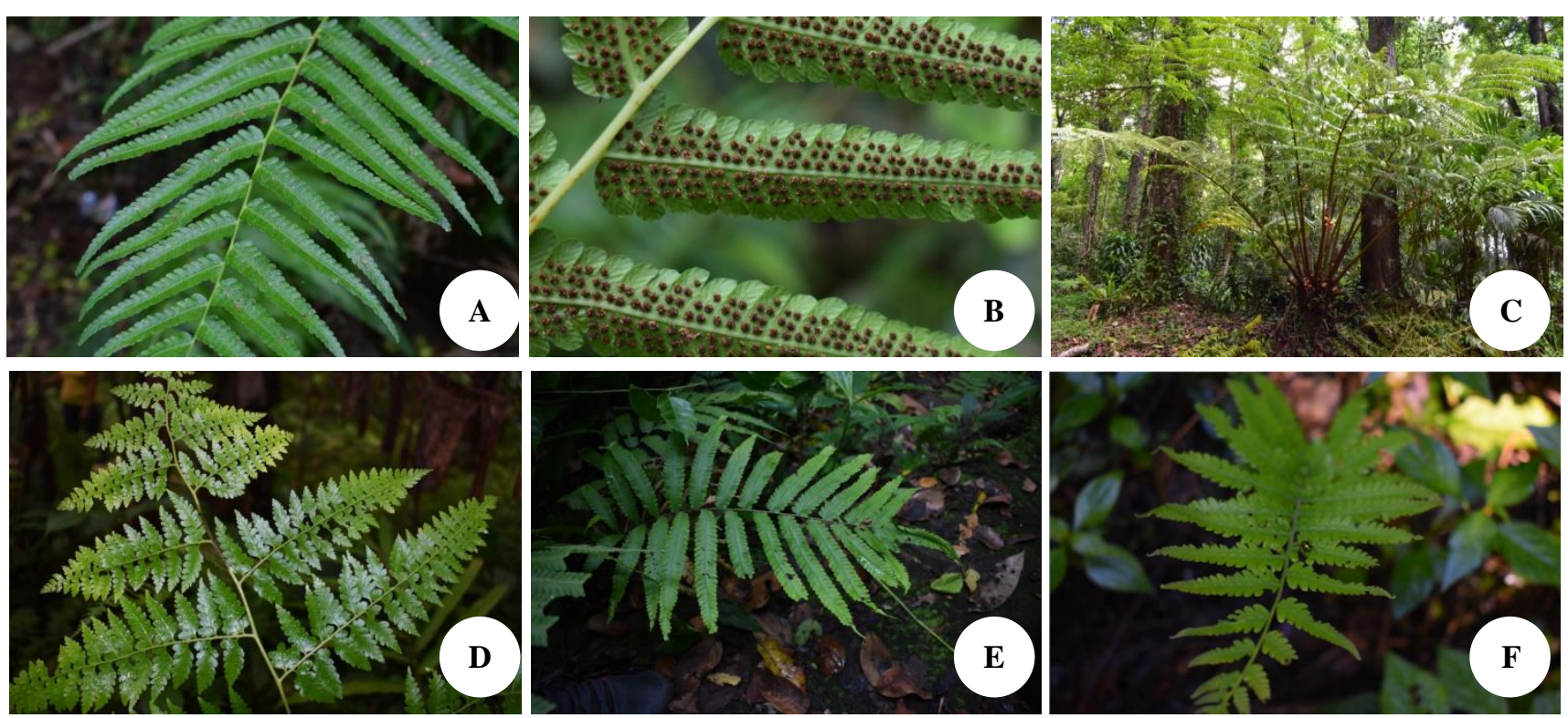

Figure 3. Dominant fern species found in various land use types in Mt. Makiling, Los Baños, Laguna, Philippines: A. Mahogany: Pneumatopteris nitidula (C. Presl) Holttum -sterile frond; B. Agriculture: Pneumatopteris nitidula (C. Presl) Holttum -fertile frond; C. Buffer: Angiopteris evecta (Forst.) Hoffm.; D. Agroforest: Davallia hymenophylloides (Blume) Kuhn; E. Roadside: Cyclosorus terminans (J. Sm. Ex Hook) K. H. Shing; F. Forest: Christella sp. 
Table 2. Pteridophytes from Mt. Makiling compared to other mountain areas

\begin{tabular}{|c|c|c|c|c|}
\hline Family & Scientific name & Mt. Pangasugan ${ }^{1}$ ) & Mt. Iraya ${ }^{2}$ ) & $\begin{array}{l}\text { Mt. Banahaw } \\
\text { 3) }\end{array}$ \\
\hline \multirow[t]{2}{*}{ Selaginellaceae } & Selaginella 1 & - & - & - \\
\hline & Selaginella cupressina (Willd.) Spring & & + & + \\
\hline Marattiaceae & Angiopteris evecta (Forst.) Hoffm. & + & + & + \\
\hline Schizaeaceae & Lygodium circinatum (Burm. f.) Sw. & + & + & - \\
\hline Lindsaeaceae & Lindsaea fissa Copel. & - & - & - \\
\hline \multirow[t]{3}{*}{ Pteridaceae } & Adiantum diaphanum Blume & - & - & - \\
\hline & Pteris blumeana C. Agardh & - & - & - \\
\hline & Pteris longipinnula Wall. ex J. Agardh & - & - & - \\
\hline \multirow[t]{2}{*}{ Dennstaedtiaceae } & Dennstaedtia philippinensis Copel. & - & - & - \\
\hline & Microlepia sp. & - & - & - \\
\hline \multirow[t]{2}{*}{ Aspleniaceae } & Asplenium sp. & - & - & - \\
\hline & Asplenium tenerum $\mathrm{G}$. Forst. & - & - & - \\
\hline \multirow[t]{5}{*}{ Thelypteridaceae } & Christella sp. & - & + & - \\
\hline & Cyclosorus terminans (J. Sm. ex Hook.) K.H. Shing & - & - & - \\
\hline & Sphaerostephanos hirsutus Holttum & - & + & + \\
\hline & Sphaerostephanos unitus (L.) Holttum & - & - & - \\
\hline & Pneumatopteris nitidula (C. Presl) Holttum & - & - & + \\
\hline \multirow[t]{3}{*}{ Dryopteridaceae } & Bolbitis heteroclita (C. Presl) Ching & - & + & - \\
\hline & Bolbitis sinuata Hennipman & - & - & + \\
\hline & Pleocnemia macrodonta Holttum & + & - & - \\
\hline Nephrolepidaceae & Nephrolepis cordifolia (L.) C. Presl & + & - & + \\
\hline \multirow[t]{2}{*}{ Tectariaceae } & Tectaria crenata Cav. & - & - & - \\
\hline & Tectaria siifolia (Willd.) Copel. & - & - & - \\
\hline Davalliaceae & Davallia hymenophylloides (Blume) Kuhn & - & - & - \\
\hline \multirow[t]{3}{*}{ Polypodiaceae } & Microsorum longissimum Fée & - & - & - \\
\hline & Phymatosorus membranifolium (R. Br.) S.G. Lu & - & - & + \\
\hline & Phymatosorus scolopendria (Burm.f.) Pic. Serm. & - & - & - \\
\hline
\end{tabular}

Note: $(-)=$ absent $(+)=$ present. $\left.^{1}\right)$ Belonias and Bañoc $(1994),{ }^{2}$ ) Barcelona (2003); ${ }^{3}$ ) Banaticla and Buot (2004)

Identified fern species were found to be distributed over large biogeographical regions (Table 3). These species are Adiantum diaphanum Blume, Angiopteris evecta (Forst.) Hoffm., Asplenium tenerum G. Forst., Bolbitis heteroclita (C. Presl) Ching, Bolbitis sinuata Hennipman, Davallia hymenophylloides (Blume) Kuhn, Dennstaedtia philippinensis Copel., Lygodium circinnatum (Burm. f.) Sw., Nephrolepis cordifolia (L.) C. Presl, Phymatosorus membranifolium (R. Br.) S.G. Lu. Ferns tend to have wider geographical ranges due to their effective dispersal via spores (Kessler 2010).

Some endemic Philippine fern species are: Phymatosorus scolopendria (Burm.f.) Pic. Serm., Pteris longipinnula Wall. ex J. Agardh, Tectaria crenata Cav. and Tectaria siifolia (Willd.) Copel. The fern species Cyclosorus terminans (J. Sm. ex Hook.) K.H. Shing is native to the Philippines while Pneumatopteris nitidula (C. Presl) Holttum is endemic to the Philippines. Despite opportunities for long-distance dispersal, some ferns have localized ranges as a result of low frequency of longdistance dispersal, habitat specialization, geographical isolation, and competitive interactions between species (Kessler 2010).

There is a need to document fern species along with its population across land use types in order to utilize ferns as plant indicators due to their vulnerability to changes in environmental conditions. These results can shed light on the appropriate strategy for the conservation and management of ferns. Hopefully, data sets gathered in this study can result to the creation of effective forest conservation measures to pteridophyte flora of Mt. Makiling. 
Table 3. List of fern species (sensu PPG 2016) found in Mt. Makiling with its corresponding distribution and conservation status

\begin{tabular}{|c|c|c|c|c|c|c|c|}
\hline Class, Order & Family & Scientific name & Distribution & Reference & Status & $\begin{array}{c}\text { Conserv- } \\
\text { ation } \\
\text { status } \\
\end{array}$ & Exsiccata \\
\hline \multirow{2}{*}{$\begin{array}{l}\text { Lycopodiopsida } \\
\text { Selaginellales }\end{array}$} & Selaginellaceae & Selaginella 1 & - & & - & NA & - \\
\hline & & $\begin{array}{l}\text { Selaginella cupressina } \\
\text { (Willd.) Spring }\end{array}$ & $\begin{array}{l}\text { Moluccas, Java, Sulawesi, Borneo, Philippines. } \\
\text { Widespread. }\end{array}$ & $\begin{array}{l}\text { http: //portal.cybertaxonomy.org } \\
\text { Leaflt. Données issues de l'INPN } \\
\text { 23/07/2019 }\end{array}$ & - & NA & 6896 \\
\hline $\begin{array}{l}\text { Polypodiopsida } \\
\text { Marattiales }\end{array}$ & Marattiaceae & $\begin{array}{l}\text { Angiopteris evecta } \\
\text { (Forst.) Hoffm. }\end{array}$ & $\begin{array}{l}\text { Occurs in far N.E. India-in Arunachal Pradesh and } \\
\text { adjacent Assam-and right through from Myanmar } \\
\text { and S.E. Asia to the Philippines. }\end{array}$ & $\begin{array}{l}\text { Boonkerd et al. Thai For. Bull. (Bot.) } \\
\text { 32: } 9.2004\end{array}$ & - & OTS & 6897 \\
\hline Schizaeales & Schizaeaceae & $\begin{array}{l}\text { Lygodium circinnatum } \\
\text { (Burm. f.) Sw. }\end{array}$ & $\begin{array}{l}\text { Sri Lanka and India to } \mathrm{S} \text { China, across Malesia to the } \\
\text { Solomons. Throughout the Philippines }\end{array}$ & $\begin{array}{l}\text { Merr.-in Philip. J. Sc. 1921: } 336 \\
\text { Sw.-in Bull. Bur. For. Philip. 1920: pl. } \\
\text { IV }\end{array}$ & - & NA & $6898-6900$ \\
\hline Lindsaeineae & Lindsaeaceae & Lindsaea fissa Copel. & Asia Tropical: Malesia: Philippines & Copeland-in Fern Fl. Philip. 1958: 105 & Endemic & NA & $6936-6937$ \\
\hline \multirow[t]{3}{*}{ Pteridinae } & Pteridaceae & $\begin{array}{l}\text { Adiantum diaphanum } \\
\text { Blume }\end{array}$ & $\begin{array}{l}\text { Native to China (Fujian, Guangdong, Hainan, } \\
\text { Jiangxi), Taiwan, Indonesia, Malaysia, Vietnam, } \\
\text { Australia, New Zealand and the Pacific islands }\end{array}$ & $\begin{array}{l}\text { Bostock, P.D. 1998: Adiantaceae. } \\
\text { Flora of Australia 48: } 248-263\end{array}$ & - & NA & $6902-6904$ \\
\hline & & $\begin{array}{l}\text { Pteris blumeana } \mathrm{C} . \\
\text { Agardh }\end{array}$ & India, Laos, Cambodia, S. Vietnam and Malesia. & $\begin{array}{l}\text { Tardieu \& C.Chr., Fl. Indo-Chine } 7 \\
\text { (2): } 157.1940\end{array}$ & - & $\mathrm{LC}$ & - \\
\hline & & $\begin{array}{l}\text { Pteris longipinnula Wall. } \\
\text { ex J. Agardh }\end{array}$ & Widespread; S India, Malesia & $\begin{array}{l}\text { Boonkerd \& Pollawatn, Pterid. } \\
\text { Thailand: } 129.2000\end{array}$ & Endemic & NA & $6908-6909$ \\
\hline \multirow[t]{2}{*}{ Dennstaedtiinae } & Dennstaedtiaceae & $\begin{array}{l}\text { Dennstaedtia } \\
\text { philippinensis Copel. }\end{array}$ & $\begin{array}{l}\text { native to Asia-Tropical, Africa, Pacific, Southern } \\
\text { America, Northern America, Australasia and Asia- } \\
\text { Temperate }\end{array}$ & Leafl. Philipp. Bot. 9: 31071920 & Endemic & NA & - \\
\hline & & Microlepia sp. & - & - & - & NA & 6910 \\
\hline \multirow{2}{*}{$\begin{array}{l}\text { Aspleniinae } \\
\text { (Eupolypods II) }\end{array}$} & Aspleniaceae & Asplenium sp. & - & - & - & NA & 6914 \\
\hline & & $\begin{array}{l}\text { Asplenium tenerum } \mathrm{G} \text {. } \\
\text { Forst. }\end{array}$ & $\begin{array}{l}\text { Australia, Bonin Isls, Borneo, Cambodia, China, } \\
\text { India, Japan, Java, Lesser Sunda Isls, Micronesia, } \\
\text { Moluccas, Myanmar, New Guinea, Nicobar Isls, } \\
\text { Pacific, Peninsular Malaysia, Ryukyu Isls, }\end{array}$ & $\begin{array}{l}\text { Handb. Ferns Brit. India: 147, f. } 74 . \\
1883\end{array}$ & - & NA & 6911-6913 \\
\hline
\end{tabular}


Cyclosorus terminans (J. Native

Sm. ex Hook.) K.H.

Shing

Sphaerostephanos Sulawesi, Philippines.

hirsutus

Sphaerostephanos unitus Sri Lanka, S India, across Malesia. Throughout the

(L.) Holttum

Pneumatopteris nitidula

(C. Presl) Holttum

Polypodiinae

(Eupolypods I) Philippines
Dryopteridaceae

\section{Bolbitis heteroclita $(\mathrm{C}$}

Presl) Ching

Bolbitis sinuato

Hennipman

Pleocnemia macrodonta Holttum

Nephrolepidaceae Nephrolepis cordifolia (L.) C. Presl

\section{Tectariaceae Tectaria crenata Cav.}

Tectaria

\section{Copel.}

Davalliaceae

Davallia hymenophylloides

(Blume) Kuhn

Polypodiaceae
Racib.-in Fl. Btzg. 1898: 183

Native

Copel., Fern Fl. Philip. 1960: 36

Holttum-in Blumea. 1977: 207

v.A.v.R., Handb. 1908: 214

Hook.-in Sp. Fil. 1862: p.p. \& t. 240B

Holttum-in Rev. Fl. Mal. 1955: f. 147

www.iucnredlist.org/details/194150/0 Endemic

Copel., Fern Fl. Philip. 1960: 257 -

E. India to S. Japan, Formosa, and Indo-China; in

(Solomon Is.)

India (Nicobar Is.) and Peninsular Thailand; in

Malesia: Sumatra, Malay Peninsula, W. Java,

Borneo, Philippines, New Guinea

Malesia: Borneo (Sarawak), Philippines (Luzon,

Sibuyan, Mindoro), E New Guinea, Admiralty Is.

New Britain.

introduced into Bermuda, French Polynesia, New

Zealand, and the United States; native in north-

eastern Australia, and is considered naturalized on

the central east coast of New South Wales

Malesia: Java (?), Lesser Sunda Islands (Flores,

Malesia: Java (?), Lesser Sunda Islands (Flores, $\quad$ Alderw., Malayan Ferns. 1917: 196

Guinea; Marianas, Solomons, New Hebrides, Rotuma Is., probably Fiji.

Asia-Tropical:

Malesia: throughout, but local in occurrence.

nophylloides Africa: Asia-Tropical; Australasia; Tropical and

Fice

(Philippines)

membranifolium (R. Br.) Sumatra, Peninsular Malaysia, Java, Lesser Sund

S.G. Lu $\quad$ Islands, Borneo, Philippines, Sulawesi, Moluccas,

Islands, Borneo, Philippines, Sulawesi, Moluccas,
New Guinea (including New Ireland). Pacific

Solomon Islands, Fiji, Society Is., Marquesas

Phymatosorus scolopendria Philippines (Luzon), Palawan; introduced in Hawaii W.C. Shieh-in Fl. Taiwan. 1994: 504 Endemic
Blumea 18: 148. 1970 - $\quad$ NA

http: //portal.cybertaxonomy.org/flora- -

malesiana/cdm_dataportal/taxon

Holttum-in Revis. Fl. Malaya, 2nd ed. 1968: 379

Endemic

Copel., Fern Fl. Philipp. 1960: $314 \quad$ Endemic

1809: t. 127

Ching-in Acta Phytotax. Sinica. 1963 -

Noot.-in Blumea. 1997: 339

NA

LC 6934-6935

(Burm.f.) Pic. Serm.

Note: *Conservation status is based from DENR list of threatened species (DAO No. 2007-01, also found in Fernando, et al. 2008). LC = Least Concern; NA = Not Assessed; OTS = Other

Threatened Species 


\section{Recommendation}

All ferns identified should be conserved and several measures should be developed to prevent their extinction. Some of these measures should include: (i) information dissemination, (ii) active participation in environmental improvement, and (iii) implementation of strict rules and regulations towards the protection of ferns to increase awareness and fern conservation. The generated information from this study, such as fern indicators, can be utilized as reference for biodiversity monitoring programs in Mt. Makiling in the future. The list of species encountered in this study can serve as baseline data for future pteridophytes research and can be enriched by further studies in the said area.

The preference of many pteridophyte species for microenvironments that can be found along the altitudinal gradient makes them vulnerable to the slightest change in environmental conditions brought by natural and manmade disturbances. Effective forest conservation measures are essential to the survival and diversity not only of the pteridophytes but also the rest of the flora and fauna of Mt. Makiling. Furthermore, it is recommended that the fern diversity and composition of the Northeastern and Southeastern portions of Mt. Makiling be compared to this study. Moreover, these could be compared to other similar forest reserves in the Philippines having the same land use types.

\section{ACKNOWLEDGEMENTS}

The authors would like to express their sincere gratitude to the Makiling Center for Mountain Ecosystems, UPLB for granting access and permit to conduct the research in Mt. Makiling Forest Reserve and to the Office of Vice Chancellor for Research and Extension (OVCRE) for funding this study.

\section{REFERENCES}

Amoroso VB. 1987b. Medicinal ferns and fern allies of Mindanao. CMU Printing Press.

Amoroso VB, Acma FM, Pava HP. 1996. Diversity status and ecology of pteridophytes in three forests in Mindanao, Philippines. In: Camus JM and Johns RJ, editors. Pteridology in Perspective. Royal Botanic Gardens, Kew.

Amoroso VB, Coritico FP, Fritsch PW. 2016. Species richness and conservation status of ferns and lycophytes in Mt. Hamiguitan Range Wildlife Sanctuary, Davao Oriental, Philippines. Philippines J Sci 145: 127-137.

Banaticla MCN, Buot Jr. IE. 2004. Fern patch structure and species diversity of Mt. Banahaw. Philippine Agric Sci 87 (1): 49-60.

Banaticla MCN, Buot Jr. IE. 2008. Identification, geographic distribution and floristic affinity of pteridophytes on the northeastern slope of Mt Banahaw de Lucban, Sierra Madre mountain range, Quezon (Luzon Island), Philippines. J Nature Stud 7 (1): 35-42.
Barcelona JF. 2002. Philippine pteridophyte collections as a resource for conservation planning. Proceedings of the "International Symposium on the Fern Flora Worldwide: Threats and Responses" sponsored by the British Pteridological Society and IUCN-Species Survival Commission." Fern Gaz 16 (6, 7 \& 8): 307-312.

Barcelona JF. 2003. The Taxonomy and Ecology of the Pteridophytes of Mt. Iraya and Vicinity, Batan Island, Batanes Province, Northern Philippines. Kluwer Academy Publishers, Netherlands.

Belonias BS, Bañoc LM. 1994. Species diversity and distribution of pteridophytes in Mount Pangasugan. Ann Trop Res 16: 30-38.

Brown WH. 1919. Vegetation of Philippine Mountains. DANR, Bureau of Science, Manila.

Buot Jr IE. 1999. Pteridophytes frequently sold at carbon market, Cebu (Philippines): implications to urban horticulture and nature conservation. Philippine Scientist, Philippines.

Buot, Jr IE., Osumi, K. 2011. Land use Type Pattern and Woody Species Composition Near Human Disturbed Landscapes on Mount Makiling, Luzon Island. Amer J Environ Sci 7 (4): 306-315.

Christenhusz, M., Toivonen, JM, Tuuli, K. 2008. Giants invading the tropics: the oriental vessel fern, Angiopteris evecta (Marattiaceae). Biol Invasions 10 (8). 1215-1228.

Delos Angeles MD, Buot Jr IE. 2012. Orders and Families of Philippine Pteridophytes. J Nature Stud 11 (1\&2): 19-33.

Delos Angeles MD, Buot Jr IE. 2018. Altitudinal Zonation of ferns along the northeastern slope of Mt. Makiling, Philippines. Sylvatrop. 28 (2): 47-68.

Fernando ES, Co LL, Lagunzad DA, Gruezo W Sm, Barcelona JF, Madulid DA, Lapis AB, Texon GI, Manila AC, Zamora PM. 2008. Threatened Plants of the Philippines: A Preliminary Assessment. Asia Life Sci Suppl 3: 1-52.

Frahm JP, Gradstein SR. 1991. An altitudinal zonation of tropical rainforests using Bryophytes. J Biol 18: 669-678.

Kessler, M. 2010. Fern Ecology. Cambridge University Press, U.K. 22-60.

Koptur S, Lee MAB. 1993. Plantlet formation in tropical montane ferns: a preliminary investigation. Amer Fern J 83 (2): 60-66.

Lee, YK, Don, KL, Woo, SY, Abraham, RG, Carandang, WM, Yeo, US, \& Park, C. 2010. Differences of tree species composition and microclimate between a mahogany (Swietenia macrophylla King) plantation and a secondary forest in Mt. Makiling, Philippines. For Sci Technol 2 (1): 1-12.

Magtoto, LM, Austria, CM. 2017. The Pteridophytes of Adams, Northern Luzon, Philippines and their Ecosystem Services. Philippine J Syst Biol 11 (2): 43-51.

Mittermeier RA, Gil PR, Mittermeier CG.1997. Megadiversity: Earth's Biologically Wealthiest Nations. CEMEX and Conservation International, Mexico City.

Pelser PB, Barcelona JF, Nickrent DL. 2011 onwards. Co's Digital Flora of the Philippines. // philippineplants.org/Families/Pteridophytes.html.

Polinar AN, Muuss U. 2010. Tree Species Diversity in Secondary Forest of Mount Pangasugan, Baybay City, Philippines. J Nat Stud 9 (1): 105-111.

PPG I. 2016. A community-derived classification for extant lycophytes and ferns. J Syst Evol 54: 563-603.

Soriano MS, Hilvano N, Garcia R, Hao AJ, Alegre A, Tiburan Jr. C. 2019. Land use/land cover change detection and urban sprawl analysis in the Mount Makiling Forest Reserve watersheds and buffer zone, Philippines. Environments. 6 (9): 1-20.

Tolentino DB. 1988. The Fern Flora of Mt. Sto.Tomas, Benguet (Luzon). [Thesis]. University of the Philippines LosBaños, College, Laguna, Philippines

Watkins, JE, Mack, ME, Mulkey, SS. 2007. Gametophyte and demography of epiphytic and terrestrial tropical ferns. Amer J Bot 94 (4): 701-708.

Zamora PM, Co L. 1986. Guide to Philippines Flora and Fauna, Vol. 2. Natural Resources Management Center and University of the Philippines, Manila. 